\title{
Keto Acid Metabolism in Desulfovibrio
}

\author{
By A. J. LEWIS AND J. D. A. MILLER \\ Corrosion and Protection Centre, University of Manchester Institute of \\ Science and Technology, Manchester M60 I QD
}

(Received 3 March 1975)

\begin{abstract}
SUMMARY
Four strains of Desulfovibrio each excreted pyruvate to a constant level during growth; it was re-absorbed when the substrate (lactate) was exhausted. Malate, succinate, fumarate and malonate also accumulated during growth.

One of the strains (Hildenborough) excreted $\alpha$-ketoglutarate as well as pyruvate when incubated in nitrogen-free medium; the former was re-absorbed on addition of $\mathrm{NH}_{4} \mathrm{Cl}$. In a low-lactate nitrogen-free medium, strain Hildenborough rapidly re-absorbed the pyruvate initially excreted, but did not re-absorb the $\alpha$-ketoglutarate. Arsenite (I mM) prevented the accumulation of $\alpha$-ketoglutarate; I mMmalonate did not affect the accumulation of keto acids.

Isocitrate dehydrogenase activity (NAD-specific) in all strains was lower than NADP-specific glutamate dehydrogenase activity. $\alpha$-Ketoglutarate dehydrogenase could not be detected in any strain. NADPH oxidase activity was demonstrated.

This and previous work indicate that a tricarboxylic acid pathway from citrate to $\alpha$-ketoglutarate exists in Desulfovibrio spp., and that succinate can be synthesized via malate and fumarate; however, an intact tricarboxylic acid cycle is evidently not present. The findings are compared with observations on biosynthetic pathways in clostridia, obligate lithotrophs, phototrophs, and methylotrophs, and various facultative bacteria.
\end{abstract}

\section{INTRODUCTION}

Desulfovibrio species utilize sulphate as terminal electron acceptor in anaerobic respiration, and simple organic substances such as lactate, malate or pyruvate as carbon sources. The tricarboxylic acid (TCA) cycle has not been shown to occur in Desulfovibrio, although several reactions of the cycle have been demonstrated (Grossman \& Postgate, 1955; Miller \& Wakerley, 1966; Gottschalk, 1968; Miller et al. 1970; Hatchikian \& Le Gall, 1970). An important reaction for the cycle, which has not been conclusively shown, is that catalysed by $\alpha$-ketoglutarate dehydrogenase.

There have been demonstrations of extracellular accumulation of $\alpha$-ketoglutarate by Pseudomonas aeruginosa (von Tigerstrom \& Campbell, 1966) and Brevibacterium flavum (Shiio, Otsuka \& Takahashi, I96I) during metabolism of substrate in the absence of ammonium ions. In the work reported here we observed the accumulation of $\alpha$-ketoglutarate and pyruvate by physiologically active Desulfovibrio vulgaris in a medium lacking combined nitrogen. The accumulation of other organic acids during the growth of Desulfovibrio spp. was also examined.

\section{METHODS}

Organisms and culture methods. Desulfovibrio vulgaris strains Hildenborough (NCIB8303) and Woolwich (NCIB8457), and D. desulfuricans strains Teddington R (NCIB8312) and Byron (NCIB8458) were grown in the chemically-defined liquid medium of Macpherson \& 
Miller (1963), which contains lactate as sole carbon source. Cultures $(200 \mathrm{ml})$ in cottonwool-plugged Pyrex conical flasks were incubated at $30^{\circ} \mathrm{C}$ in McIntosh \& Fildes anaerobic jars under $\mathrm{H}_{2}$. Growth was measured by determining extinction at $600 \mathrm{~nm}$.

Cultures for nitrogen starvation studies were harvested aseptically, before growth was complete, by centrifuging at $15000 \mathrm{~g}$ for $5 \mathrm{~min}$. The organisms were then washed in sterile tris- $\mathrm{HCl}$ buffer $(0.1 \mathrm{M}, \mathrm{pH} 7 \cdot 2)$, recentrifuged, and suspended in $200 \mathrm{ml}$ sterile nitrogen-free (non-growth) medium which differed from the original medium in containing 5 or $50 \mathrm{mM}$ sodium lactate but no $\mathrm{NH}_{4} \mathrm{Cl}$. After incubation as before, cultures were centrifuged at $20000 \mathrm{~g}$ for $15 \mathrm{~min}$ to remove the bacteria, the supernatants then being adjusted to $\mathrm{pH} 7.4$.

Chromatography. The g.l.c. technique was a modification of the method of Harman \& Doelle (1969). Methyl esters of the TCA cycle intermediates, along with those of lactate, pyruvate and malonate, were prepared by the method of Harman \& Doelle (1969). Supernatant samples $(50 \mathrm{ml})$ were dried in a rotary vacuum evaporator at $40{ }^{\circ} \mathrm{C}$; the residues were esterified, dissolved in chloroform and $5 \mu \mathrm{l}$ injected onto a column of $10 \%$ Reoplex on acidwashed Chromosorb W (60 to 80 mesh). Columns, I m $\times 6.3 \mathrm{~mm}$ (obtained from Phase Separations Ltd, Queensferry, Chester) were used on a Pye ro4 gas chromatograph using a temperature programme from 50 to $190^{\circ} \mathrm{C}$ at $6{ }^{\circ} \mathrm{C} / \mathrm{min}$ and a final holding period of $10 \mathrm{~min}$.

Quantitative estimation of organic acids. Commercial enzymes for use in the assays were obtained from Sigma.

Lactic acid was measured enzymically by an adaptation of the method of Rosenberg \& Rush (1966). Glycine-semicarbazide buffer was prepared daily: $\mathrm{I} \cdot 5 \mathrm{~g}$ glycine $+2 \cdot 2 \mathrm{~g}$ semicarbazide in $80 \mathrm{ml}$ distilled water were adjusted to $\mathrm{pH}$ io with $2 \mathrm{M}-\mathrm{NaOH}$ and made up to $100 \mathrm{ml}$. The assay mixture contained $(\mathrm{ml}):$ buffer, $2 \cdot 8 ; \mathrm{NAD}^{+}(5 \mathrm{mg} / \mathrm{ml}), 0 \cdot 6$; sample, $0 \cdot 2$. The extinction at $340 \mathrm{~nm}$ was read $\left(E_{1}\right)$ before the addition of $0.4 \mathrm{ml}$ lactate dehydrogenase (beef heart; 20 units $/ \mathrm{ml}$ ). The mixture was then incubated at $40^{\circ} \mathrm{C}$ for $2 \mathrm{~h}$ and the $E_{340}$ again read $\left(E_{2}\right)$. A blank containing distilled water instead of the sample was set up at the same time and readings taken $\left(B_{1}\right.$ and $\left.B_{2}\right)$. The net change in extinction, $\Delta E$, as a result of the NADH formed by the oxidation of lactate to pyruvate was given by

$$
\Delta E=\left(E_{2}-0.9 E_{1}\right)-\left(B_{2}-0.9 B_{1}\right) .
$$

Pyruvic and $\alpha$-ketoglutaric acids were measured both chemically and enzymically. By the chemical method of Goodwin \& Williams (1952), both acids were measured in one assay. Pyruvate was determined enzymically by the method of Rosenberg \& Rush (I966). $\alpha$-Ketoglutarate was measured using glutamate dehydrogenase. The assay mixture contained $(\mathrm{ml})$ : tris- $\mathrm{HCl}$ buffer (0.05 M, pH 7.4), I.7; $\mathrm{NADH}(2 \mathrm{mg} / \mathrm{ml}), 0.1 ; \mathrm{NH}_{4} \mathrm{Cl}$ (0.I M), 0.1 ; glutamate dehydrogenase (bovine liver; 25 units $/ \mathrm{ml}$ ), $0 . \mathrm{I}$; sample, $\mathrm{I} \cdot 0$. The reaction was followed at $340 \mathrm{~nm}$ and the initial rate of the reaction compared with a calibration curve. All extinctions were determined on a Beckman DB spectrophotometer; enzyme units are expressed as that amount which catalyses the removal of I $\mu \mathrm{mol}$ substrate in I min at $30^{\circ} \mathrm{C}$.

Preparation of extracts. Bacteria were grown in 41 batches and harvested using a continuous flow head attachment on an MSE I8 centrifuge (flow rate 30 to $50 \mathrm{ml} / \mathrm{min}$ ). The bacteria were then resuspended in tris- $\mathrm{HCl}$ buffer $(0.05 \mathrm{M}, \mathrm{pH} 7.4)$, the suspension placed in a French press and the bacteria disrupted at $20000 \mathrm{lb} / \mathrm{in}^{2}(13 \cdot 7 \mathrm{MPa})$. The extract was centrifuged at $15000 \mathrm{~g}$ for $30 \mathrm{~min}$, the supernatant decanted in $\mathrm{I} \mathrm{ml}$ portions and stored below $0{ }^{\circ} \mathrm{C}$.

Assay of isocitrate dehydrogenase (EC. I.I.I.4I). As extracts of the bacteria contain a NADH oxidase (Germano \& Anderson, 1968), it was impossible to measure the enzyme activity by following $\Delta E_{340}$ because of NAD formation. Instead, the enzyme was assayed 
by examining the effect of isocitrate on the oxidation of NADH in the presence of NAD. The assay mixture contained (per $3.0 \mathrm{ml}$ ): isocitrate, Io $\mu \mathrm{mol}$; NAD, $0.3 \mu \mathrm{mol}$; NADH, $0.26 \mu \mathrm{mol} ; \mathrm{MnSO}_{4}, 5 \mu \mathrm{mol}$; tris- $\mathrm{HCl}$ buffer $\mathrm{pH} 7.4,125 \mu \mathrm{mol}$; cell-free extract, $0 . \mathrm{I} \mathrm{ml}$. $\mathrm{NADH}$ oxidation was measured using the above mixture without isocitrate; isocitrate dehydrogenase activity was the difference between the two rates.

Assay of aconitate hydratase (EC. 4.2.1.3). This was measured by determining the amount of isocitrate formed from cis-aconitate using isocitrate dehydrogenase (NADPspecific). During the course of these experiments NADPH oxidase activity was observed, which interfered with the assay. A similar assay was therefore used to that for isocitrate dehydrogenase above. The mixture contained (per 3.0 ml): tris- $\mathrm{HCl}$ buffer $\mathrm{pH} 7 \cdot 4,125 \mu \mathrm{mol}$; aconitate, $15 \mu \mathrm{mol}$; NADP, $0.3 \mu \mathrm{mol}$; NADPH, $0 . \mathrm{I} \mu \mathrm{mol} ; \mathrm{MnSO}_{4}, 5 \mu \mathrm{mol}$; isocitrate dehydrogenase (NADP-specific, pig heart), 10 units; cell-free extract, $0^{\circ} . \mathrm{I} \mathrm{ml}$. The reference cuvette contained the same except for the NADPH and cis-aconitate, which were used to start the reaction. The NADPH oxidation rate was measured in the absence of aconitate.

Assay of $\alpha$-ketoglutarate dehydrogenase. The NADH oxidase also affected this assay, so a similar method to that for isocitrate dehydrogenase was used. The mixture contained (per $3.0 \mathrm{ml}$ ): tris- $\mathrm{HCl}$ buffer $\mathrm{pH} 8.2,125 \mu \mathrm{mol} ; \mathrm{MgCl}_{2}, 5 \mu \mathrm{mol}$; NAD, $0.3 \mu \mathrm{mol}$; NADH, $0.26 \mu \mathrm{mol}$; cysteine- $\mathrm{HCl}, 3 \mu \mathrm{mol}$; thiamin pyrophosphate, $0.2 \mu \mathrm{mol}$; coenzyme $\mathrm{A}$, $0 \cdot \mathrm{I}$ $\mu \mathrm{mol} ; \alpha$-ketoglutarate, $10 \mu \mathrm{mol}$; cell-free extract, $0.1 \mathrm{ml}$. The reference cuvette contained all these components except NADH and $\alpha$-ketoglutarate, which were used to start the reaction. The rate of NADH oxidation was measured in the absence of $\alpha$-ketoglutarate.

Another assay was also used, based on the colorimetric determination of ferrocyanide produced by the oxidative decarboxylation of $\alpha$-ketoglutarate with ferricyanide as electron acceptor (Hager, 1953).

Assay of glutamate dehydrogenase (EC. I .4. I .4). This enzyme was assayed spectrophotometrically by following the oxidation of NADPH in the presence of $\alpha$-ketoglutarate and $\mathrm{NH}_{4}{ }^{+}$at $340 \mathrm{~nm}$. The mixture contained (per $3.0 \mathrm{ml}$ ): tris- $\mathrm{HCl}$ buffer $\mathrm{pH} 7.4,130 \mu \mathrm{mol}$; $\alpha$-ketoglutarate, Io $\mu \mathrm{mol} ; \mathrm{NH}_{4} \mathrm{Cl}$, Io $\mu \mathrm{mol}$; NADPH, $0.3 \mu \mathrm{mol}$; cell-free extract, $0 . \mathrm{I} \mathrm{ml}$. NADPH oxidation was measured in the above mixture without $\alpha$-ketoglutarate.

\section{RESULTS}

\section{Keto acid accumulation}

In all the strains examined, pyruvate was the only keto acid to accumulate during growth in the complete medium of Macpherson \& Miller (1963). Pyruvate formed rapidly and thereafter remained at a constant concentration (Fig. I). In medium containing $5 \mathrm{mM}-$ lactate (carbon-limiting) the pyruvate disappeared as the lactate was used up (Fig. 2).

There was a similar excretion of pyruvate by all strains in 100 mM-lactate nitrogen-free medium after transfer from full growth medium; strain Hildenborough also excreted $\alpha$-ketoglutarate. In a $5 \mathrm{~mm}$-lactate nitrogen-free medium the pyruvate initially excreted by strain Hildenborough was subsequently utilized along with lactate, but the $\alpha$-ketoglutarate was not utilized (Fig. 3). The other strains did not excrete $\alpha$-ketoglutarate in the low-lactate nitrogen-free medium, and when $\alpha$-ketoglutarate was added to this medium it was not utilized. Figure 4 shows the results obtained with strain Teddington R; strains Woolwich and Byron gave closely similar results.

Clearly, ammonium ions suppressed $\alpha$-ketoglutarate excretion into full growth medium by strain Hildenborough, while their addition to a suspension of this strain in nitrogen-free medium rapidly stopped the accumulation of the keto acid and allowed it to be utilized 


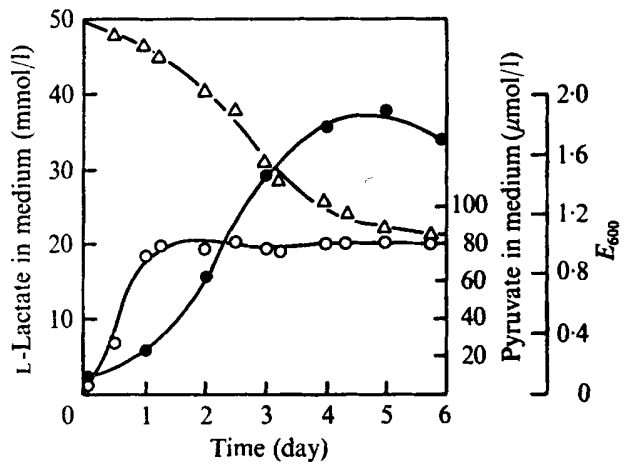

Fig. I

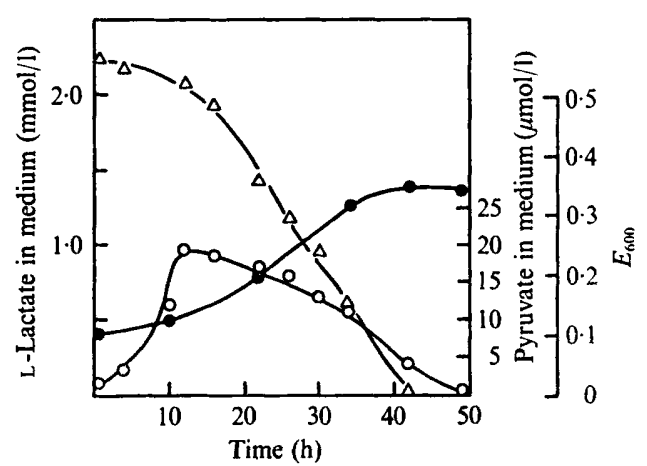

Fig. 2

Fig. I. Concentration of lactate $(\triangle)$ and pyruvate $(O)$ in the medium, during growth $(O)$ of D. vulgaris strain Hildenborough in Macpherson \& Miller's (1963) medium.

Fig. 2. Concentration of lactate $(\triangle)$ and pyruvate $(O)$ in the medium, during growth $(0)$ of strain Hildenborough in a 5 mM-lactate modification of Macpherson \& Miller's (1963) medium.

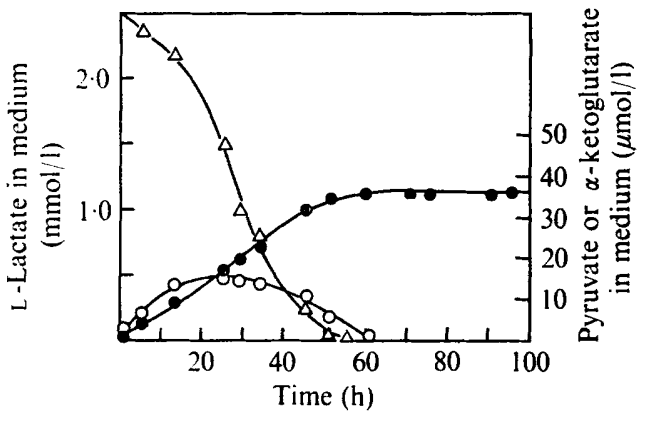

Fig. 3

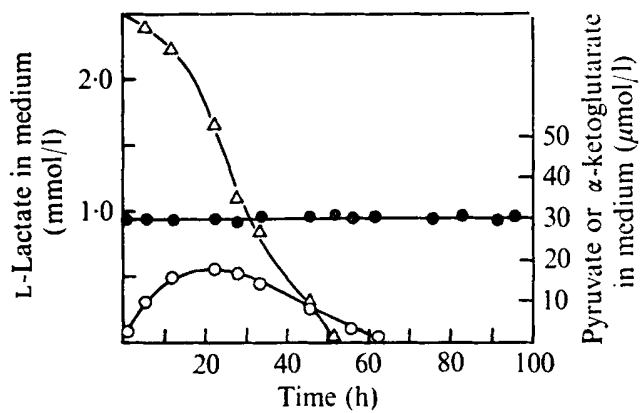

Fig 4

Fig. 3. Concentration of lactate $(\triangle)$, pyruvate $(O)$ and $\alpha$-ketoglutarate $(0)$, in the cell-free supernatant from a suspension of strain Hildenborough in a $5 \mathrm{~mm}$-lactate nitrogen-free medium.

Fig. 4. Concentration of lactate $(\triangle)$, pyruvate $(O)$ and $\alpha$-ketoglutarate $(\Theta)$, in the cell-free supernatant from a suspension of $D$. desulfuricans strain Teddington $\mathrm{R}$ in 5 mM-lactate nitrogen-free medium with $30 \mu \mathrm{M}-\alpha$-ketoglutarate added.

(Fig. 5). A similar uptake of $\alpha$-ketoglutarate by the three other strains was observed on addition of ammonium ions to the nitrogen-free medium with added $\alpha$-ketoglutarate, as shown for strain Teddington $R$ in Fig. 5.

Malonate (I mM), an inhibitor of succinate dehydrogenase, had no effect on the accumulation of keto acids, while arsenite (I mM), an inhibitor of pyruvate and $\alpha$-ketoglutarate dehydrogenases, prevented the accumulation of $\alpha$-ketoglutarate, as also observed by Neumann (1967) with strain Hildenborough.

\section{Accumulation of other acids}

Gas-liquid chromatography of the supernatant medium after growth of strains Hildenborough and Teddington $\mathrm{R}$ showed that both strains excreted malate, fumarate, succinate and malonate during growth. Strain Hildenborough also excreted an acid which though not positively identified, had a similar retention time to butyrate. 


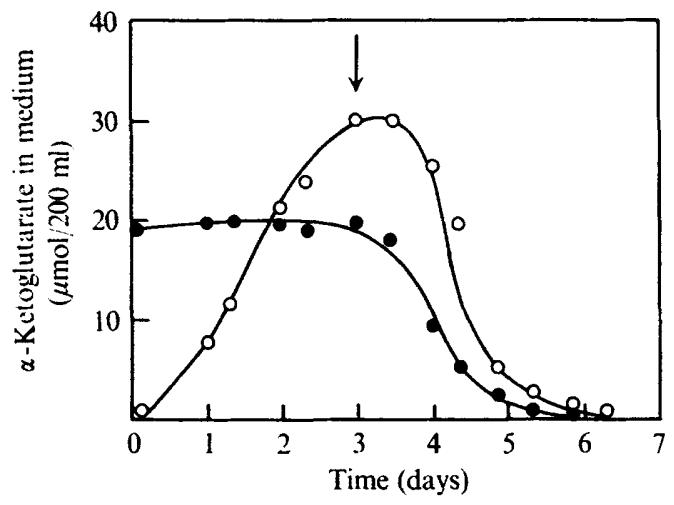

Fig. 5. Uptake of $\alpha$-ketoglutarate by strains Hildenborough and Teddington $\mathrm{R}$ suspended in nitrogen-free medium, after addition (arrow) of 10 mM- $\mathrm{NH}_{4} \mathrm{Cl}$. $\bigcirc$, Strain Hildenborough, with no added $\alpha$-ketoglutarate; $\bullet$, strain Teddington R, with $100 \mu \mathrm{M}$ - $\alpha$-ketoglutarate added.

Table 1. Levels of certain enzymes in four strains of Desulfovibrio

For details of assay conditions, see Methods.

\begin{tabular}{|c|c|c|c|c|}
\hline & \multicolumn{4}{|c|}{ Specific activity (units/g protein) } \\
\hline & \multicolumn{2}{|c|}{ D. vulgaris } & \multicolumn{2}{|c|}{ D. desulfuricans } \\
\hline & $\begin{array}{c}\text { Strain } \\
\text { Hilden- } \\
\text { borough }\end{array}$ & $\begin{array}{c}\text { Strain } \\
\text { Woolwich }\end{array}$ & $\begin{array}{l}\text { Strain } \\
\text { Tedding- } \\
\text { ton R }\end{array}$ & $\begin{array}{l}\text { Strain } \\
\text { Byron }\end{array}$ \\
\hline Aconitate hydratase & $3 \cdot 4$ & $3 \cdot 3$ & $3 \cdot 7$ & $4 \cdot 0$ \\
\hline Isocitrate dehydrogenase & $7 \cdot 2$ & $6 \cdot 6$ & $7 \cdot 5$ & $7 \cdot I$ \\
\hline Glutamate dehydrogenase & $4 \mathrm{I} \cdot 0$ & $38 \cdot 0$ & $38 \cdot 0$ & $40 \cdot 0$ \\
\hline NADH oxidation & $10 \cdot 0$ & $9 \cdot 1$ & $9 \cdot 6$ & $8 \cdot 6$ \\
\hline NADPH oxidation & $I \cdot I$ & 0.9 & I. 5 & $\mathrm{I} \cdot 4$ \\
\hline
\end{tabular}

In a parallel experiment, these two strains were grown in full medium as above, centrifuged before growth was complete, and resuspended in fresh growth medium to which I mM-arsenite or I mM-malonate had been added. Gas-liquid chromatography of the resulting culture supernatant gave very similar results. Since arsenite inhibits $\alpha$-ketoglutarate synthesis but not that of malate, fumarate or succinate, $\alpha$-ketoglutarate cannot be a precursor of these acids.

\section{Enzyme levels}

The enzymes of $\alpha$-ketoglutarate metabolism were estimated in all four strains (Table I). Formation of $\alpha$-ketoglutarate by isocitrate dehydrogenase was found to be low compared with its conversion to glutamate. The isocitrate dehydrogenases were shown to be NADspecific; the glutamate dehydrogenases were NADP-specific. No activity of $\alpha$-ketoglutarate dehydrogenase was detected by two different assay methods.

\section{DISCUSSION}

The accumulation of pyruvate by Desulfovibrio in full growth medium and nitrogen-free medium must be due to the initial conversion of lactate to pyruvate being faster than the utilization of pyruvate. Some control, however, must be exerted so that the extracellular pyruvate concentration remains unchanged. Why $\alpha$-ketoglutarate is excreted into the 
nitrogen-free medium only by $D$. vulgaris, strain Hildenborough, of the four strains examined is not clear. Macpherson \& Miller (I963) showed that the Hildenborough strain grew poorly on glutamate or glutamine as sole carbon source, but they did not grow the organism on $\alpha$-ketoglutarate. As $\alpha$-ketoglutarate is not used in nitrogen-free medium when other carbon sources are exhausted, the bacteria are probably unable to oxidize it. Since the keto acid disappears rapidly when ammonium ions are added to the medium, presumably to glutamate, a permease must be present.

Although $\alpha$-ketoglutarate dehydrogenase activity was not detected in cell-free extracts, this does not prove conclusively that the enzyme is absent. As isocitrate dehydrogenase activity is much lower than that of glutamate dehydrogenase, any $\alpha$-ketoglutarate formed would immediately be used for glutamate synthesis, rather than oxidized with a TCA cycle.

The accumulation of $\alpha$-ketoglutarate only by strain Hildenborough is possibly due to the systems of $\alpha$-ketoglutarate production in the other three strains being subject to endproduct repression.

Gottschalk (1968) has shown that $\alpha$-ketoglutarate is not formed via succinate in sulphatereducing bacteria; hence the effect of arsenite in inhibiting $\alpha$-ketoglutarate formation must be on pyruvate dehydrogenase. This means that malate, succinate and fumarate could not be formed via the TCA cycle in the conventional direction. A possible sequence is malate $\rightarrow$ fumarate $\rightarrow$ succinate, with malate arising from pyruvate by the action of the malic enzyme. Malonate has no effect on the accumulation of these acids. Some support for this sequence comes from the work of Barton \& Peck (I97I) and Barton, Le Gall \& Peck (1973), who used particulate preparations of Desulfovibrio gigas.

These findings all point to the existence of an incomplete TCA cycle in Desulfovibrio, having only a biosynthetic function. This is similar to what is currently understood of the functions of the cycle in anaerobic bacteria. Incomplete TCA cycles in clostridia (Stern \& Bambers, 1966), in Desulfovibrio and in anaerobically grown Escherichia coli indicate that anaerobes use only parts of the cycle as biosynthetic pathways. In $E$. coli, $\alpha$-ketoglutarate dehydrogenase is repressed on transfer to anaerobic conditions (Amarasingham \& Davis, I965) and a reductive pathway to succinate becomes operative (Hager \& Kornberg, 196I). The cycle then operates as two separate biosynthetic pathways.

Obligate lithotrophs (Smith, London \& Stanier, 1967; Johnson \& Abraham, 1969; Peeters, Liu \& Aleem, 1970; Tabita \& Lundgren, 1971), obligate phototrophs (Fuller et al. I96I; Smith et al. 1967; Pearce, Leach \& Carr, 1969) and obligate methylotrophs (Colby \& Zatman, 1972; Dahl, Mehta \& Hoare, 1972) have also been shown to lack a complete cycle or to possess one whose enzymes are very much lower in activity than those in the facultative members of each group.

The lack of $\alpha$-ketoglutarate dehydrogenase and NADH oxidase in strict autotrophs was put forward as a biochemical explanation of their inability to grow heterotrophically by Smith et al. (1967). NADH oxidase has, however, been found in autotrophs (Aleem, 1968; Trudinger \& Kelly, 1968), though the presence of an incomplete cycle remains a possible explanation.

We are grateful to the Science Research Council for a research grant in support of this work, and for a research studentship awarded to A.J.L.

\section{REFERENCES}

AleEM, M. I. H. (1968). Mechanism of oxidative phosphorylation in the chemoautotroph Nitrobacter agilis. Biochimica et biophysica acta 162, 338-347. 
Amarasingham, C. R. \& DaVIS, B. D. (1965). Regulation of $\alpha$-ketoglutarate dehydrogenase formation in Escherichia coli. Journal of Biological Chemistry 240, 3664-3668.

Barton, L. L., Le Gall, J. \& Peck, H. D. (1973). In Horizons of Bioenergetics, p. 33. Edited by A. San Pietro and H. Gest. New York: Academic Press.

Barton, L. L. \& PeCK, H. D. (1971). Phosphorylation coupled to electron transfer between lactate and fumarate in cell-free extracts of the sulfate-reducing anaerobe, Desulfovibrio gigas. Bacteriological Proceedings, I49.

Colby, J. \& Zatman, L. J. (1972). Hexose phosphate synthase and tricarboxylic acid cycle enzymes in bacterium 486, an obligate methylotroph. Biochemical Journal 128, 1373-I 376.

DahL, J. S., MEhtA, R. J. \& HoARE, D. S. (1972). New obligate methylotroph. Journal of Bacteriology Iog, 916-921.

Fuller, R. C., Smillie, R. M., Sisler, E. C. \& Kornberg, H. L. (196I). Carbon metabolism in Chromatium. Journal of Biological Chemistry 236, $2140-2149$.

Germano, G. J. \& Anderson, K. E. (1968). Purification and properties of L-alanine dehydrogenase from Desulfovibrio desulfuricans. Journal of Bacteriology 96, 55-60.

Goodwin, T. W. \& WiLliams, G. R. (1952). Studies on vitamin A. XVIII. The effect of vitamin A deficiency on the pyruvate and $\alpha$-ketoglutarate levels of rat blood. Biochemical Journal 51, 708-714.

GotisChaLK, G. (1968). The stereospecificity of the citrate synthase in sulfate-reducing and photosynthetic bacteria. European Journal of Biochemistry 5, 346-35I.

Grossman, J. P. \& Postgate, J. R. (1955). The metabolism of malate and certain other compounds by Desulphovibrio desulphuricans. Journal of General Microbiology 12, 429-445.

HAGER, L. P. (1953). Ph.D. thesis, University of Illinois.

HAGER, L. P. \& KORNBERG, H. L. (1961). On the mechanism of $\alpha$-oxoglutarate oxidation in Escherichia coli. Biochemical Journal 78, 194-198.

Harman, M. A. \& Doelle, H. W. (I969). Gas chromatographic separation and determination of microquantities of the esters of the tricarboxylic acid cycle acids and related compounds. Journal of Chromatography 42, I57-169.

Hatchikian, E. C. \& Le Gall, J. (1970). Étude du métabolisme des acides dicarboxyliques et du pyruvate chez les bactéries sulfato-reductrices. Annales de l'Institut Pasteur 118, I25-142.

Johnson, E. J. \& ABRAham, S. (1969). Assimilation and metabolism of exogenous organic compounds by the strict autotrophs Thiobacillus thioparus and Thiobacillus neapolitanus. Journal of Bacteriology 97, I 1981208.

MacPherson, R. \& Miller, J. D. A. (I963). Nutritional studies on Desulfovibrio desulfuricans using chemically defined media. Journal of General Microbiology 31, 365-373.

Miller, J. D. A., Neumann, P. M., Elford, L. \& WakerLey, D. S. (1970). Malate dismutation by Desulfovibrio. Archiv fïr Mikrobiologie 7r, 214-219.

MiLleR, J. D. A. \& WAKERLEY, D. S. (1966). Growth of sulphate-reducing bacteria by fumarate dismutation. Journal of General Microbiology 43, 101-107.

NeUMANN, P. M. (1967). Investigations into the carbon metabolism and growth inhibition of sulphate-reducing bacteria. M.Sc. thesis, University of Manchester.

Pearce, J., Leach, C. K. \& Carr, N. G. (1969). The incomplete tricarboxylic acid cycle in the blue-green alga Anabaena variabilis. Journal of General Microbiology 55, 371-378.

Peeters, T. L., Liu, M. S. \& Aleem, M. I. H. (1970). The tricarboxylic acid cycle in Thiobacillus denitrificans and Thiobacillus A2. Journal of General Microbiology 64, 29-35.

Rosenierg, J. C. \& Rush, B. F. (I966). An enzymatic-spectrophotometric determination of pyruvate and lactic acid in blood. Methodologic aspects. Clinical Chemistry 12, 299-307.

Shmo, I., Otsuka, S. \& TAKAHASHI, M. (1961). Significance of $\alpha$-ketoglutaric dehydrogenase on the glutamic acid formation in Brevibacterium flavum. Journal of Biochemistry 50, I64-165.

SmTth, A. J., London, J. \& StanieR, R. Y. (1967). Biochemical basis of obligate autotrophy in the blue-green algae and thiobacilli. Journal of Bacteriology 94, 972-983.

SteRn, J. R. \& BAMBERS, G. (1966). Glutamate biosynthesis in anaerobic bacteria. I. The citrate pathways of glutamate synthesis in Clostridium kluyveri. Biochemistry 5, II I 3-1 I 8.

TABITA, R. \& LundGren, D. G. (1971). Heterotrophic metabolism of the chemolithotroph Thiobacillus ferrooxidans. Journal of Bacteriology 108, 334-342.

von Tigerstrom, M. \& CAMPBell, J. J. R. (I966). Accumulation of $\alpha$-ketoglutarate by suspensions of Pseudomonas aeruginosa. Canadian Journal of Microbiology 12, 1005-1013.

Trudinger, P. A. \& Kelly, D. P. (1968). Reduced nicotinamide adenine dinucleotide oxidation by Thiobacillus neapolitanus and Thiobacillus strain c. Journal of Bacteriology 95, 1962-1963. 